\title{
INCREASING THE ECONOMY OF VILLAGE COMMUNITY THROUGH BANANA WASTE MANAGEMENT
}

\author{
Nanning $^{1}$, Ahmad Abbas ${ }^{2 *}$, Abd Rauf Ibrahim ${ }^{1}$, Mujahidah ${ }^{1}$ \\ ${ }^{I}$ English Education Department, Tarbiyah Faculty, Institut Agama Islam Negeri Parepare, Pare-Pare, Indonesia \\ ${ }^{2}$ Accounting, Faculty of Economics and Islamic Business, Institut Agama Islam Negeri Parepare, Pare-Pare, \\ Indonesia \\ *Correponding Author: ahmad.abbas@stainparepare.ac.id
}

\begin{abstract}
The program of this community service is designed to increase the village economy through the waste recycle. This program aims to assist the community in Tanete Village of Sidenreng Rappang of South Sulawesi to increase the family economy by utilizing the banana waste. It was carried out using Participatory Action Research (PAR) approach. The sample of village community consisted of twenty people in Tanete Village of Sidenreng Rappang of South Sulawesi. The stages of its implementation were socialization, training and demonstration. The result of this program encouraged the village community successfully to make banana waste become the painting and food jam.
\end{abstract}

Keywords: Banana Waste; Economy; Village.

\section{INTRODUCTION}

Village is the unity of the legal community that has the right to take care of its own household based on the right of origin and customs recognized by the national government in the district. Village is a law unit where the community resides in a separate government. the sense of community is a structure or action which is essentially determined by hopes and values dominant in the citizens. The characteristics of the village community are as follows:

a) The relationship of the citizens is very close

b) Generally live from agricultural products

c) Group life system based on family system

d) How to farm is not familiar with agricultural mechanisms

e) Old age people play an important role in tradition D call formal leadership

f) Social control system is very powerful so that the development of individual soul is very difficult in developing

g) A very strong sense of fraternity between societies

In the life of Indonesian, villagers have a living system in general groups with a family basis. Most of the rural people have a job as a farmer. Jobs that are outside the farm are the usual sideline work to fill your spare time. Rural communities in Indonesia are homogeneous, as in terms of livelihood, religion, customs, and so on. In addition, the lives of rural people in Indonesia are identical with the term and team which is a cooperation to achieve common interests.

Community empowerment needs to be undertaken to improve community skills in the economic sphere. The imbalance between development in the city and in the village also has a bad social and economic impact on life in both areas of society. The city will have a higher population density due to open employment opportunities in various fields. Conversely, the condition in the village is increasingly deserted by its citizens, remaining residents who only rely on the agricultural sector, managed with the traditional system and depending on the season and land conditions. This condition occurs because people try to find a place or area that is relatively more potential both on occasion and economically. On the other hand, the condition of the village economy is increasingly fragile because of the reduced workforce that chooses to move to urban areas than those that persist in the traditional farming conditions that are less yielding and provide revenue quickly and directly.

Thus above circumstances tend to be experienced by most people in developing countries, including Indonesia. It is difficult to avoid because the economical mechanism of acceleration in the city will clearly defeat economic growth in rural areas.

Within some cases, the city often has a modern and dynamic vision, while the character villages are sluggish and traditional. Addressing this condition is time for the Government to make efforts towards its policies in building village communities, especially in the era of regional autonomy. The government needs to also study strategies for 
creating the harmony of the development between villages and cities as a consequence of the implementation of district autonomy. The development of rural areas is very important, because the rural economic structure is in an unfavorable state compared to urban structures. So how to grow and develop development in the countryside as well as what efforts to be done to achieve harmony with the city territory is a homework that needs to be answered immediately.

Banana is a commodity that widely consumed by Indonesian people. The fruit is easy to grow in Indonesia. The data center and Agricultural Information Systems (Pusat Data \& Sistem Informasi Pertanian, 2016) noted that the development of banana production in Indonesia until the period 2015. The average growth is $4.16 \%$ per year. Based on data from the South Sulawesi Statistical Centre (BPS), the production of banana commodities in Sidrap Regency is as much as 8,258.5 tons and the 6th largest banana production in South Sulawesi province. Bananas become one of the many fruits that are sold in the district of Marritenggae at Sidrap regency. Central statistical agency (BPS, 2017) illustrates that its population was only 278 people in 2012. The number is at least 12 villages/neighborhoods in Marritenggae district. The population in 2016 increased sharply to 3,071 people. As people grow, employment is also required.

Every market found in Marritenggae district sold a lot of bananas. Banana sales are also found around the village Helios even some residents have banana trees around rumanhya. So far, the village community at Marritenggae is quite fond of bananas. Some people in there sometimes get tired of consuming banana meat which basically they only process it for frying. The study was designed to be able to map the potential and problems of local resources in the improvement of the village economy, an understanding of the needs of information for the improvement of the village economy and to develop a strategy for the development of village economics through participatory approaches.

Some previous studies about banana waste management have been conducted by Rahmiati et al. (2018), Suharyani et al. (2014) and Wilar et al. (2014). They have encouraged their communites to utilize the banana skin to be commercial products.

\section{METHOD}

This program uses the type of qualitative study with the PAR (participatory Action Research) approach. The three PRA-steps used. First is persuasive approach. This approach focuses on the ideas, attitudes, and efforts of the community on the basis of directional and selective contact that comes from outside parties to create motivation, creation and innovation for the people to be able to think and do according to the truth. Second is Andragogy. It is a science that discusses approaches in learning interactions between educators and learners who are age-old to the participation principal and art for the local community in learning and teaching. Third is institutional approach that takes into account the linkage and agreement with the service of government and private agencies and social organizations in accelerating the process of development and modern thinking, creative and innovative.

In order to change the side condition for the better, the PAR method is used to provide understanding for the business actors. PAR is beneficial for the facility and motivating assistance by subjects to be able to:

a) Identify the strengths and weaknesses.

b) Find the problem causing factors and alternative solutions.

c) Strategize and correct methods to solve problems .

d) Develop action plan based on priorities and sustainability of the program through stages so that targets can be achieved.

This research was held in Tanete Village office of Sidenreng Rappang regency by conducting material teaching and training gradually. First is a talk and discussion on economic enhancement and benefits of bananas. The second is the training and demonstration with the practice of banana skin processing to be handicraft products worth selling. Housewives and business people in Tanete village, especially the field of craft and culinary involved as target/research target.

\subsection{Mentoring Steps}

The steps of mentoring are as follows.

a) Socialization of $50 \%$ is namely lectures and discussions on economic enhancement and benefits of bananas. Socialization is the process of social interaction through which we know ways of thinking, feeling and behave, so that it can participate effectively in society.

b) Training and demonstration of 50\%. Banana skin processing practice becomes a selling value cuisine product.

For the community, socialization serves as a means to preserve, disseminate, and bequeath the values, norms, and beliefs that exist in the community. That ways are the values, norms, and beliefs that can be guarded by all members of the community. Socialization differentiated over two stages. Primary socialization as the first socialization undertaken by individuals during childhood, through which he became a member of the community, in this phase the primary socialization process establishes the child's personality into the public and the family that serves as 
Socialization agents. Secondary socialization is defined as the next process that introduces individuals who have been socialized into a new sector of the world's objective. In this stage the socialization process leads to the realization of the attitude of professionalism; And in this case being a socialization agent is an educational institution, a peer group, a job institution, a wider environment of the family.

The purposes of socialization are as follows.

a) Every individual must be given the skills needed for his future life in the community

b) Every individual must be able to communicate effectively and develop his ability to read, write and speak.

c) Control of organic functions should be learnt by appropriate self-introspection exercises.

d) Each individual must be familiarizing with the fundamental values and beliefs of the community.

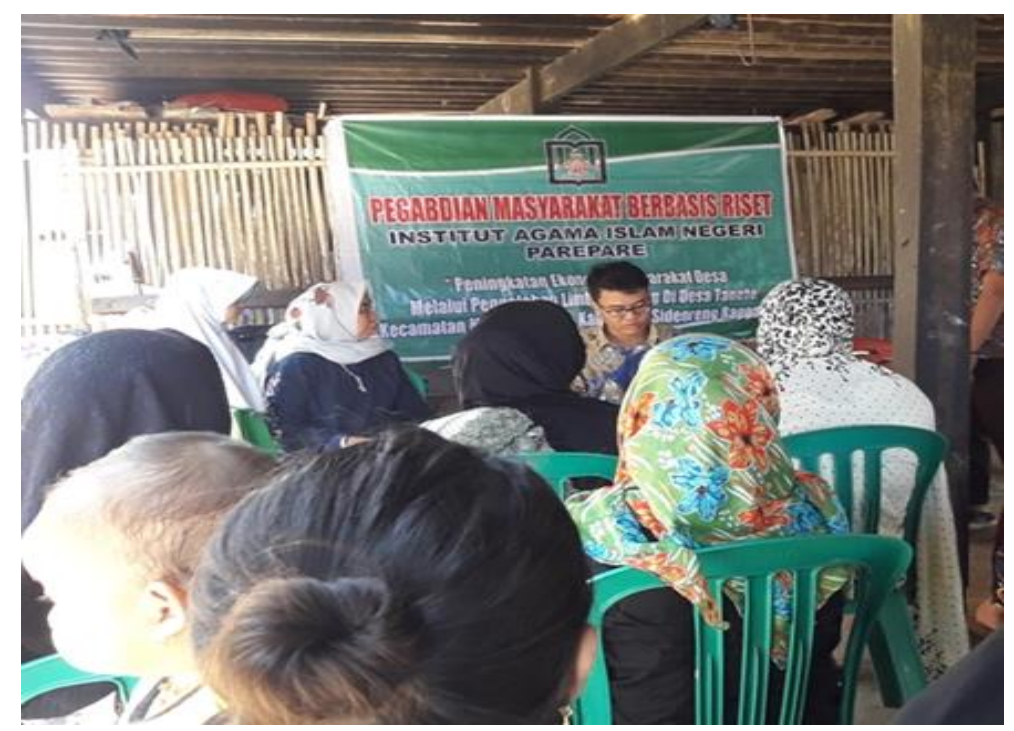

Figure 1. Socialization and Discussion.

\section{RESULTS AND DISCUSSION}

Tanete Village has a place of $9.11 \mathrm{~km} 2$ with a percentage of $13.82 \%$ of villages on sub-districts of Marritenggae. The number of households is 724 neighborhoods with a population of 3,071 people. Most of Tanete villagers are only able to cultivate banana meat in a way that is fried or made of Molen and Kolak. Banana bark is always made waste by them. The number of fried banana and Molen snacks around the village needs the basic ingredients of bananas, but banana skin is always discarded and becomes garbage in its place. In addition to banana bark, banana stem is one that is considered less beneficial, while banana steam can be made handicrafts that are commercially valued.

Empowering the village community to increase its economy into the main highlights considered. Training and mentoring focused to IRT or housewives who sold fried bananas and bananas of traders in Tanete Kec Marrsumarnggae village Sidrap Regency.

The assistance by is the mother-housewife who opened the sale of fried bananas and merchants in Tanete Marrsumarma village, Sidrap Regency. They sell in front of the house and some on the roadside of the highway. To increase revenues, business variations need to be done. Banana skin processing is a valuable commodity to be implemented in Tanete village community. By relying on banana main ingredient, Helios villagers are able to increase their business income.

The selection of processed banana bark into economic value-added commodities based on consideration is as follows

1) High enough raw material productivity

2) Easy to be treated because of the simplicity of technology, and

3) The amount of capital needed can be affordable for small business people, as well as

4) Market share for the business segment processed banana skin is still minimal.

Banana (Musa Paradisiacal) is a horticultural crop that has the potential of production (banana fruit) is quite large because the banana production takes place without getting to know the season. Banana fruit is well-liked from various people because of the many nutritional content that is contained in it is vitamin, sugar, water, protein, fat, fiber and storing adequate energy. More and more people who love banana fruit then the volume of waste of the resulting banana skin is higher. The presence of waste banana skin is found in the surrounding environment so that it can pollute the environment in Tanete. Banana bark is the waste of the production of the remaining snacks (such as banana chips, 
banana jam, etc.) which usually only serve as livestock feed. Nutritional content of the king's banana skin is $91.50 \%$ organic material, $0.90 \%$ protein, crude lipid $1.70 \%$, carbohydrate $59 \%$, and crude fiber $31.70 \%$ (Anhwange et al., 2009).

Banana peels are a considerable amount of waste (banana fruit). In general, banana skin has not been utilized in real. It is only disposed of as organic waste alone or used as livestock food such as goat, cow, and buffalo. A considerable amount of banana skin will have a beneficial selling value when it can be used as food raw material.

a) Painting

The stem of banana is utilized as the main ingredient in making hand-crafted paintings. The tools and materials that are prepared are banana stem, fox glue, ruler (alternative) and plywood or can also use cork. Type of free banana, the stem of good banana is that already dried in the tree, the condition of the banana's stem completely dry (not wet or moist), the stem does not need to be dried in the sun (quite windy only). It is no need to use preservatives or added artificial dyes, because it will eliminate the natural impression of the painting. The color pattern of banana stem that will be used adapted to the needs of painters, according to the style and theme of painting.

A painting has become unnecessary in the lacquer ware (painting material). To be more beautiful can be used frame and glass. To make the painting durable and durable, avoid the painting from wet/moist. Then the other material is glue. There is no special type of glue for this painting. Glue commonly used for example; Glue Fox. Cork is used for painting grounds. Way of forging a banana's stem like pasting something is in general. Once pasted, let it dry.

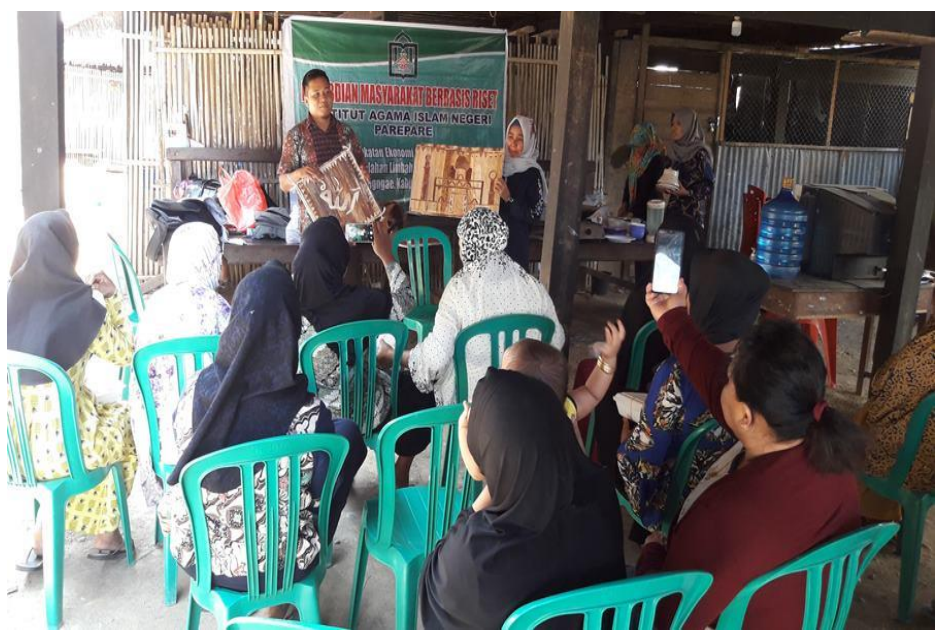

Figure 2. Painting.

b) Food Jam

Banana Jam is a high sugar-rated pasta ingredient and made from banana pulp. Making this material is not difficult, and the cost is not expensive. With a relatively low processing cost and good taste makes banana jam making a business opportunity. In this training, banana waste from the skin is used as the main ingredient in jam making.

\section{Materials used:}

- Banana Kepok leather, 250 grams

- Water, $300 \mathrm{cc}$

- Granulated sugar, 300 grams

- Jelly/Pudding, 1 sachet

- Glass Packaging, 1 Package

- Gas

Used Tools:

- Pan

- Sieve

- Fried Pan

- Blender

- Teaspoons

- Plastic measuring cup

- Cake Scales

- Stove

- Plates 
- Procedure

As for the way of making:

1) Peel the banana and separate it from the peel.

2) Wash thoroughly and drain.

3) Cut to small and weigh (250 grams) then blender.

4) Put the banana peel in a pot containing $300 \mathrm{cc}$ of water.

5) Boil +20 minutes, add the citric acid slightly when the skin of the banana is changing slightly of the color.

6) Turn off the fire and let the water cool cold for 24 hours and closed.

7) Filter the pot contents, enter the water stew to the fry pan then squeeze to get the advice.

8) Enter banana skin juice into the fry pan with the pot contents.

9) Boil for 30 minutes, add 300 grams of sugar then stir until thickened.

10)At the time of thickening, add a bit of soda and essence to get a delicious flavor.

\subsection{Demonstration process}

The process of making jam from banana bark is done gradually. All equipment and fixtures are provided especially the basic ingredients of banana skin. Here is the process of processing activities accompanied by images.

\section{A. Initial process}

- Peel the bananas and separate them from the skin.

- Wash thoroughly and drain.

- Cut to small and weigh weight (250 grams) then blender.

- Put the banana peel in a pot containing $300 \mathrm{cc}$ of water.

\section{B. The second process}

1) boil +20 minutes, add the citric acid slightly when the skin of the banana is changing color somewhat brownie.

2) Turn off the fire and let the water cool cold for 24 hours and closed.

3) Filter the pot contents, enter the water stew to fry pan then squeeze to get the advice.

4) Enter banana water juice to the fry pan together with the pot.

5) Boil for 30 minutes, add 300 grams of sugar then stir until thickened.

6) At the time of thickening, add a bit of soda and essence to get a delicious flavor.

\section{Serving process}

In this effort, jam products that are made can also be modified with the addition of banana seasoning (syrup). This is done so that the resulting jam has a distinctive aroma of banana and disguised the flavor of the banana skin so that it can attract the hearts of consumers. In addition to variant banana flavor that can be offered include: Chocolate flavor and Mocca.

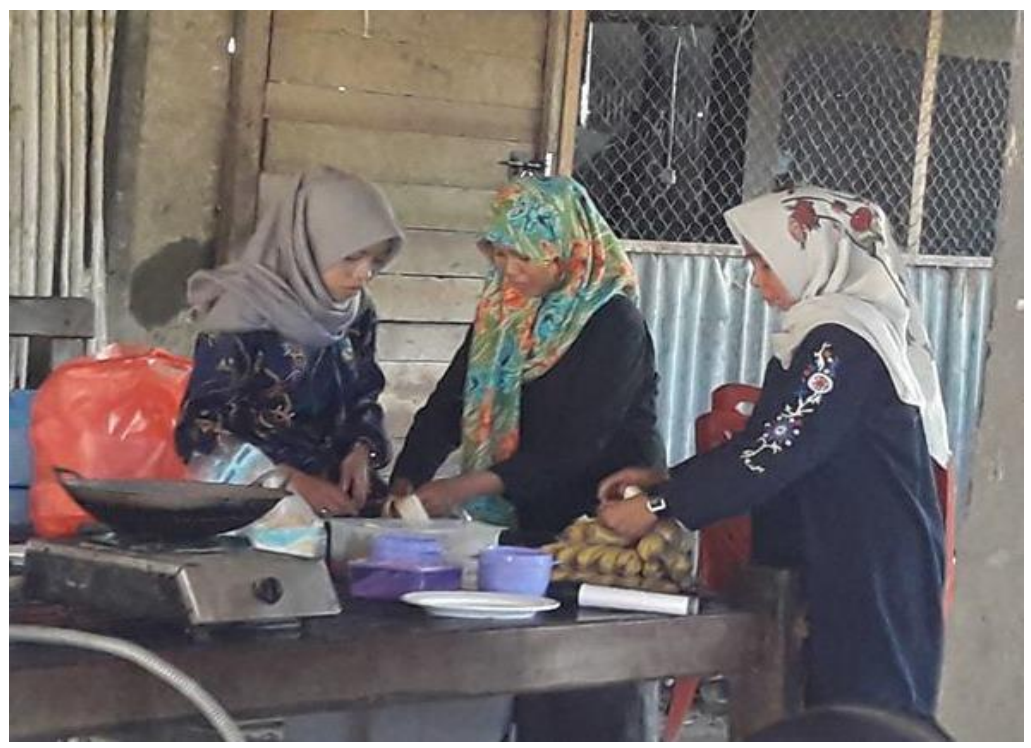

Figure 3. Process of making food jam. 
Business analysis making crafts painting from banana stem

- Capital of raw materials and tools

$\begin{array}{lc}\text { Banana Stem } & \text { Rp- } \\ \text { Scissors } & \text { Rp 5,000 } \\ \text { Glue } & \text { Rp 5,000 } \\ \text { Cork } & \text { Rp 7,500 } \\ & \text { Rp } \mathbf{1 7 , 5 0 0}\end{array}$

- Sales Opportunity

The sale of paintings can be estimated from the production price used, glue and cork into consumables in production. Production prices will be more expensive when packaged using a glass-wrapped frame. In addition, the level of difficulty in design and drawing is an additional wage.

Here are the details:

Table 1. Sales details Paintings

\begin{tabular}{|c|c|c|}
\hline & Production price & Wage settlement \\
\hline Simple painting price & $12.500,-$ & $4.500 \times 3 \mathrm{jam}$ \\
\hline
\end{tabular}

So the price per unit $\operatorname{Rp} 25,000,-$. The painting price is adjusted to the design and packaging frame made. The business analysis of the banana leather jam making

- Raw Materials Capital

\begin{tabular}{lc} 
Banana Skin & \multicolumn{2}{c}{ Rp- } \\
300g granulated sugar & Rp 7,000 \\
Agar-agar 1 pack & Rp 5,000 \\
Glass Packaging 1 Package & Rp 15,000 \\
Gas & Rp 25,000 \\
Corn flour & $\underline{\text { Rp 5,000 }}$ \\
Amount & Rp 57,000
\end{tabular}

- $\quad$ Sales Opportunity

Capital to make jam Rp 57,000 with the amount of jam produced 20 pieces so that 1 pc production price Rp 2,850.

Table 2. Details of Jam Sales

\begin{tabular}{|c|c|c|}
\hline Cost of Goods Sold & Selling price & Profit \\
\hline $\mathrm{Rp} 2.850$ & $\mathrm{Rp} 4.000$ & $\mathrm{Rp} 1.150$ \\
\hline
\end{tabular}

\subsection{Quality of products made}

The quality of the resulting banana leather jam should be a priority. In one-time production cycle of banana leather jam from $1 \mathrm{~kg}$ of banana bark, the amount of jam produced is as much as $30 \mathrm{cup} / \mathrm{PC}$ Jam ready to sell. Each package contains $50 \mathrm{ml}$ of jam ready consumption. This business holds a fast working principle with satisfactory results. As a result, consumers will still glance at this business and become its customers. Consumers who will be targeted sales come from every community, both young and old. Because Jam is an additional food ingredient that is suitable as a complement in consuming bread.

In handicraft, the utilization of banana's stem as a working media is not also free from various obstacles i.e. banana stem easily torn and easily moldy when stored or after finished work made. However, these constraints do not mean that they cannot be overcome. The stem of banana should not be dried in a place that is too hot, but it is quite windy only in a shade. If you want, to be more flat or smooth, can use an iron, but in use it should not be too harsh and the ironing is done from one direction only. The easy to moldy stem should be dried or dried until completely dry. The stem of banana is stored in a dry and not moist place. The stem that has been painted bananas should be coated with silica gel, namely small grains (chemicals) that can absorb moisture or by means of coated wood glue or lacquer ware so as to reduce the possibility of moldy.

Banana skin processing activities become economical products are expected to overcome problems. The abundance of banana skin waste into handicrafts and jam that many people demand so that the banana skin that previously only a waste can be processed into a more attractive form of food and can be consumption by the wider community. Banana skin processing becoming banana skin candy is also expected to improve the welfare of the village community. It is because the banana skin has a high economical value compared with unprocessed banana skin shells, so it is expected With this activity able to move the conjugation of village society, farmers are able to increase the prosperity to be moved into a more prosperous and happy society from its economic side 


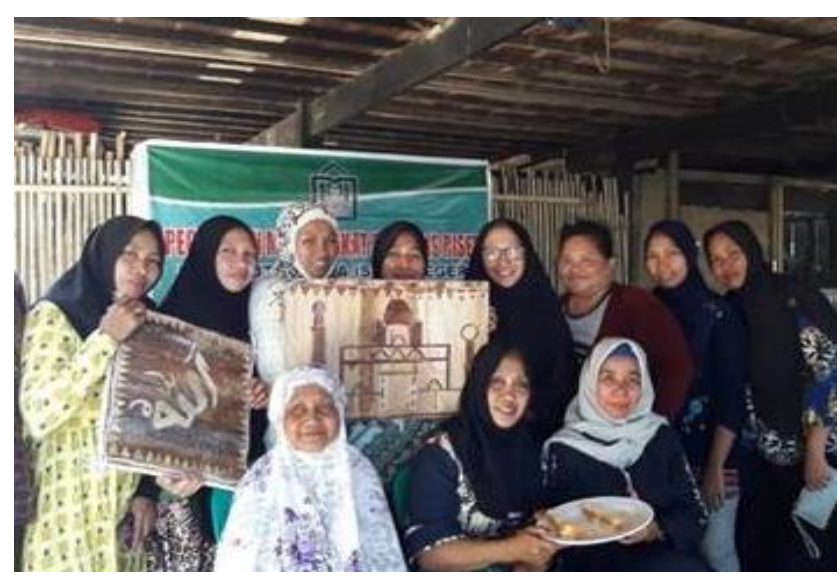

Figure 4. The Result of Product Made.

The abundance of banana farming results does not necessarily become potential, without balanced with the mastery of science and technology in banana processing then the change of bananas to produce new problems. Further, the low level of village community education became a separate problem in the process of banana production after harvesting. Cheap price has a systemic impact on the capital level of the farmer group so that the process of increasing production and diversification of processed banana production can be achieved.

\section{CONCLUSION}

The use of banana waste is rarely done by the society in Tanete so that the program of banana waste is required. It can be a work of art that is economical value. Banana skin can be utilized to be food jam. In additio, it is also used as a painting and can be developed to be main ingredient in the manufacture of wall hangings, miniature houses, canvas, souvenirs, and so on. It also makes banana stem as material in making flower arrangement, tissue box, doll, and others. Based on the explanation, researchers are eager to conduct research on the utilization of banana stem as a medium to work in Tanete.

Theoretically, the results of the training are expected to contribute to the thinking and benchmark studies on further research. Fine art learning can be implemented without being limited to commonly used media. Various types of media work can support the achievement of basic competencies expressing themselves through pure artwork developed from the art elements of the archipelago. In an effort to improve the quality of education and develop the aesthetic sensitivity of society, there is expected to study more varied art in the future.

Based on the results of the training activities that have been conducted in Tanete village particularly Maritengngae of Sidenreng Rappang, people are aware that banana waste is considered to be a waste that can be processed into jams and crafts paintings. The waste of banana skin that is considered as garbage with little drug processing technology can be transformed into a basic material of high durability banana skin and has a high selling value so that it can empower the economy of village community.

Regarding the follow-up evaluation done, it was found that people of Tanete-dominated village mothers in training following the implementation of the program have a consistent knowledge of banana waste treatment skills. Some practical benefits obtained by mothers in the village Tanete are as follows. First, they obtain clear and intact information about the nature of community empowerment in terms of knowledge and skills, meaningful to the creation of new jobs that are innovative in the development of the home industry of homemakers. Second, the trainees obtain a clear picture of the step of business climate development. Third, the trainees also get a clear and intact picture of the benefits of waste if it is managed properly.

The conclusion that can be obtained from the implementation of the program of this community is the high responses of community service partners to continue the implementation of the program.

\section{ACKNOWLEDGEMENT}

The authors would like to thank the Institute of Research and Community Service of IAIN Parepare for the grant so that the program of this community service provided the benefit to village community in Tanete of Sidenreng Rappang of South Sulawesi.

\section{REFERENCES}

Anhwange, B, J.T, Ugye \& TD, Nyiatagher. (2009). Chemical Composition of Musa Sepientum (Banana) Peels. Electronic Journal of Environmental, Agricultural and Food Chemistry, 8(6): 437-442. 
Wilar, G, Indiyanti, W. \& Subarnas, A. (2014). Pemanfaatan dan Pengolahan Limbah Kulit Pisang menjadi Permen Kulit Pisang yang Berkhasiat Antidepresi dalam Upaya Pemberdayaan Kesehatan dan Perekonomian Masyarakat Desa di Kecamatan Karang Tengah Kabupaten Cianjur. Dharmakarya: Jurnal Aplikasi IPTEKS untuk Masyarakat, 3(1), 5-8.

BPS. (2015). Produksi Buah-buahan Menurut Kabupaten/Kota Jenis Buah di Provinsi Sulawesi Selatan (Ton). Badan Pusat Statistik Sulawesi Selatan.

BPS. (2017). Kecamatan Marritenggae Dalam Angka 2017. Badan Pusat Statistik Kabupaten Sidenreng Rappang.

Pusat Data \& Sistem Informasi Pertanian. (2016). Outlook Komiditas Pertanian Subsektor Hortikultura: Pisang. Kementerian Pertanian.

Rahmiati, C.F, Hasibuan, \& D.N, Anggraeni. (2018). Pembuatan Selai Kulit Pisang. Jurnal Jurnal Prodikmas Hasil Pengabdian Masyarakat, 2(1), 78-83.

Suharyani, D. Mutiari, \& M. Solikin. (2014). Pemanfaatan Limbah Pelepah Pisang Raja Susu untuk Bahan Material Dinding Kedap Suara. Simposium Nasional RAPI XIII. 